Yields in 1918 of the major food crops were as follows, according to unrevised estimates: 2,749,198,000 bushels of corn; 918,920,000 bushels of wheat; 1,535,297,000 bushels of oats; $236,505,000$ bushels of barley; 76,687,000 bushels of rye; 18,370,000 bushels of buckwheat; $41,918,000$ bushels of rice; $61,182,000$ bushels of kafirs; $390,101,000$ bushels of Irish potatoes; 88,114,000 bushels of sweet potatoes; $17,802,000$ bushels of commercial beans; $40,185,000$ bushels of peaches; $10,342,000$ bushels of pears; 197,360,000 bushels of apples; $6,549,000$ tons of sugar beets; $29,757,000$ gallons of sorghum sirup; $52,617,000$ bushels of peanuts.

The estimated 1918 production of all the cereals, 5,638,077,000 bushels, compares with $5,796,332,000$ bushels in 1917 , and $4,883,819,000$ bushels, the annual average in the five-year period 1910-14. On January 1, 1918, it is estimated there were on American farms 21,563,000 horses, compared with an average of $20,430,000$ in the five years $1910-14 ; 4,824,000$ mules, compared with $4,346,000 ; 23,284,000$ milch cows, compared with $20,676,000 ; 43,546$,000 other cattle, compared with $38,000,000$; $48,900,000$ sheep (an increase, for the first time in many years, over the preceding year), compared with $51,929,000$; 71,374,000 swine, compared with $61,865,000$.

The estimated 1918 production of beef, $8,500,000,000$ pounds, compares with 7,384,007,000 pounds in $1917 ; 10,500,000,000$ pounds of pork compared with $8,450,148,000 ; 495,000,000$ pounds of mutton and goat meat compared with $491,205,000 ; 8,429,000,000$ gallons of milk produced in 1918 was $141,000,000$ pounds more than the 1917 production; $299,921,000$ pounds of wool, 18,029,000 pounds more than 1917; $1,921,000,000$ dozens of eggs, $37,000,000$ dozens more; $589,000,000$ head of poultry, $11,000,000$ more.

\section{THE EDWARD K. WARREN FOUNDATION AND TWO WILD LIFE RESERVATIONS IN MICHIGAN}

IT will be of interest to zoologists and botanists, particularly ecologists and those interested in the fauna and flora of the Middle West, to learn what two areas in southwestern
Michigan have been set aside as wild life preserves. The tracts comprise 300 acres (150 or more of the original forest) situated two and a half miles north of Three Oaks, in Chickaming Township, Berrien County, and over 250 acres in the sand dune region on the shore of Lake Michigan, in Lake Township, two miles north of Sawyer, in Berrien County.

The forest is a remnant of the original beech-maple forest of southern Michigan. It has never been cut or burned over and many of the trees are splendid specimens, fifty to seventy feet in height to the first limb, and from two to four feet in circumference. The Galien River flows through the forest for about one and one half miles' and there are numerous springs.

The sand dune tract has a frontage on Lake Michigan of about 3,000 feet. It includes probably the highest dunes in the State of Michigan, the largest of which are from two hundred to three hundred feet in height. Much of the tract is wild and with little doubt the original vegetation prevails in most places.

The preserves have been established by Mr. and Mrs. Edward K. Warren, of Three Oaks, Michigan, and are incorporated in the "Edward K. Warren Foundation," which also includes the Chamberlain Memorial Museum at Three Oaks, founded in 1915 and opened to the public in 1916.

The forest has been in Mr. Warren's possession for forty years, and has been preserved by him for its great natural beauty, and both tracts have been set aside that future generations may have an example of the primitive floral and fauna conditions in southern Michigan, that nature lovers may find here many of the animals and plants which are being exterminated elsewhere, and that students of biology may have available a place where they can study native animals and plants in their natural habitats. Some of the sand dune area has been more recently acquired, and it is typical of the good judgment and foresight of $\mathrm{Mr}$. Warren that this area includes the best developed dunes and is the least disturbed tract in the sand dune region. The Museum of Zoology of the University of 
Michigan has been asked to make a detailed survey of the reservations, and it is planned to extend this survey over an indefinite number of years. Field laboratories will be provided by the foundation, and the museum will send specialists on the groups represented in the preserves to these laboratories at different times. The object of the field work will be to obtain a complete inventory of the plants and animals and to secure data upon the causes of fluctuations in numbers of individuals, that the fauna and flora may be maintained as nearly as possible in the primitive condition. At the same time it is expected that ecological data and information on the original biota will be obtained which will be of scientific interest. The specimens will be deposited in the Museum of Zoology and the Chamberlain Memorial Museum, and the published results of the work will appear from the Museum of Zoology under a common title.

Future generations will not fail to appreciate the good judgment and public spirit which have led to the recognition of the desirability of insuring the perpetuity of the wild life of these areas and the establishment of the preserves.

MUSEUM OF Zoology, UNIVERSITY OF MICHIGAN

THE ORGANIZATION OF YALE UNIVERSITY AND THE SHEFFIELD SCIENTIFIC SCHOOL

Meeting in extraordinary session on December 16, with but one member absent, the Yale Corporation reviewed the whole subject of university reconstruction, and voted fundamental changes which, when carried through, will radically alter the university organization. The important votes are as follows:

1. Voted, That the recommendation of the governing board of the Sheffield Scientific School that the undergraduate course "be lengthened from three to four years" be approved.

2. That in the opinion of the corporation the reasons which led to the establishment and maintenance of a course of "Selected studies in language, literature, history and the natural and social sciences" under the administration of the faculty of the Sheffield Scientific School are no longer valid.

3. That the governing board of the Sheffield Scientific School be requested to appoint a committee, of which the director shall be chairman, to prepare plans for the immediate establishment of a four-year undergraduate course and the discontinuance of the " select" course; reporting at the same time to the corporation whether, in the opinion of this committee, it is desirable to establish a scientific course in preparation for business.

4. That this committee be directed to confer with a similar committee to be appointed by the permanent officers of Yale College regarding the inter-departmental problems created by the proposed changes, in order that properly qualified students in either school may be given access to the courses of instruction offered by the other.

5. That the president be directed to call meetings of the two committees thus created, together with the chairman of the entrance examination committee, to devise means for carrying more fully into effect the policy of joint administration of entrance requirements for the two schools; with authority to recommend, for the consideration of the respective governing boards and the approval of the corporation, such changes as shall appear to them desirable in the scope of the entrance requirements themselves, and in the organization of the freshman year.

6. That in the opinion of the corporation it is practicable, as recommended by the executive board of the graduate school, to place the administration of all advanced degrees and certificates in science, comprising at present the degree of master of science, the certificate in public health, and the higher engineering degrees, under the jurisdiction of the graduate school, without interfering with the development of the departments of study concerned or their proper articulation with the undergraduate courses which lead up to them; and that under these circumstances the administration of the courses leading to these degrees should be transferred to the graduate school at the close of the present academic year. 